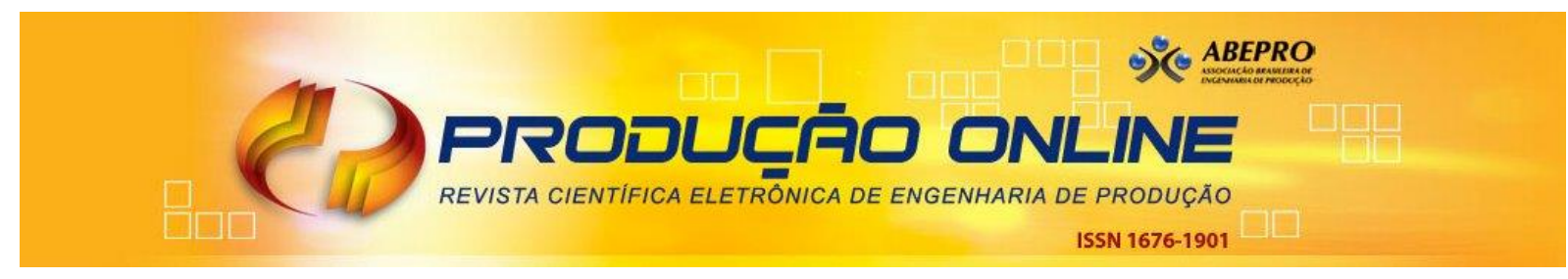

\title{
ANALYSIS OF SUPPLY CHAIN STRATEGIES: A CASE STUDY IN A SMALL- SIZED ENTERPRISE
}

\section{ANÁLISE DAS ESTRATÉGIAS DA CADEIA DE FORNECIMENTO: UM ESTUDO DE CASO EM UMA PEQUENA EMPRESA}

\author{
Fernanda Raquel Roberto Pereira* Email: fernandaraquel @hotmail.com.br \\ Dallas Walber Ferraz Segundo*Email: dallasferraz@gmail.com \\ Marcele Elisa Fontana* Email: marcele.elisa@ufpe.br \\ *Universidade Federal de Pernambuco (UFPE), Caruaru (PE), Brasil
}

\begin{abstract}
Through well-defined Supply Chain Strategies (SCS), a company establishes long-term relationships with customers and suppliers, and also explores new options for processes, increases productive efficiency, and consequently delivers better customer service. There are methodologies developed to assist companies assessing their SCS performance. They are usually applied to largesized companies, where there is a well-defined structure. Nevertheless, this scenario is generally not observed in micro and small-size enterprises (MSEs), where a limited number of employees accumulates functions, and there is no clear division of departments. Therefore, the main aim of this work was to adapt a SCS evaluation methodology to MSE. A case study was analysed to demonstrate the proposed adaptation. The proposed methodology allowed the manager to identify and understand the relationships between the objectives in a logical way. In addition, it allowed a better assessment of the context, acting as a guide in the strategy formulation process.
\end{abstract}

Keywords: Conceptual system. Strategy in Organizations. Business Unit. Soft operational research. Apparel industry.

Resumo: Através de Estratégias de Cadeia de Suprimentos (SCS) bem definidas, uma empresa estabelece relacionamentos de longo prazo com clientes e fornecedores e, também, explora novas opções para processos, aumenta a eficiência produtiva e, consequentemente, oferece melhor atendimento ao cliente. Existem metodologias desenvolvidas para auxiliar as empresas na avaliação do desempenho do SCS. Elas geralmente são aplicadas em empresas de grande porte, onde há uma estrutura bem definida. No entanto, esse cenário geralmente não é observado em micro e pequenas empresas (MPEs), onde as funções são acumuladas por um número limitado de funcionários e não há divisão clara de departamentos. Portanto, o principal objetivo deste trabalho foi adaptar uma metodologia de avaliação da SCS para uma MPE. Um estudo de caso foi analisado para demonstrar a adaptação proposta. A metodologia proposta permitiu ao gestor identificar e compreender as relações entre os objetivos de forma lógica. Além disso, permitiu uma melhor avaliação do contexto, atuando como um guia no processo de formulação da estratégia.

Palavras-chave: Sistema conceitual. Estratégia nas Organizações. Unidade de negócio. Pesquisa Operacinal Soft. Indústria de confecção.

\section{INTRODUÇÃO}

Globalization and fierce market competition have driven companies in their search for technological development and differentiation of their products and services 
to meet the customers' needs (Vitorino Filho et al., 2017). In this sense, the adoption of modern management systems, integrating strategies, seeking more efficient processes and generating capacities in partnership to carry out logistics activities, has become a successful key factor in the business environment (Hsiao et al., 2010). For that, companies seek to integrate into Supply Chains (SC), which extend and enhance their internal potential, based on trust and the collaborative relationship (Ritchie and Brindley, 2007). They are increasingly motivated by efficient coordination of their decisions (Hlioui et al., 2015). In this scenario, competitiveness is increasingly sought between chains and not more between business units alone (Di Serio and Sampaio, 2001; De Carvalho Gomes and Kliemann Neto, 2015). Thus, Supply Chain Management (SCM) is rapidly growing as a strategic initiative, driven by globalization, global sourcing, emphasis on time and quality based competition and their contributions to the environmental uncertainty (Chong et al., 2009).

A well-structured SCM is fundamental for gaining competitive advantages over the competition, as well as improving performance in the market (Omar et al., 2012). However, in order to implement the SCM, a system shared is necessary, comprising a same set of values, beliefs and instruments, between all the companies that belong to a supply chain (Mentzer et al., 2001). Moreover, the SC for a product should be appropriately aligned with the characteristics of that product and the market for which it is intended (Golicic and Sebastiao, 2011). Therefore, the main goal of SCM is to increase the synergy between chain links, seeking a higher level of customer satisfaction, reducing costs and increasing aggregate value. Roh et al. (2014) argued that SC practices built on strategies can improve the business performance of companies and their partners by increasing their competitiveness.

Thus, according to Narasimhan et al. (2008), in the global competitive environment in which companies operate nowadays, developing a successful Supply Chain Strategy (SCS) is critical to a company's long-term competitive success. A low level of chain integration tends to result in weak responses to market changes (Kim and Cavusgil, 2009). In this sense, Lima-Junior and Carpinetti (2007) identified five main SCS, which are lean, agile, flexible, green and sustainable.

The five aforementioned types are a set of practices and ideas used to guide both planning and action. In a business unit, the plans may be at the tactical or operational levels of all hierarchically subordinate sectors to areas considered of Revista Produção Online. Florianópolis, SC, v. 19, n. 4, p. 1262-1288, 2019 
interest to the success of the SCM (Perez-Franco, 2016). Hence, SCS has an important mediating role between such practices and the central ideas of top management.

Therefore, the strategy formulation that guides the SCM of any company should be pursued in a deliberate manner and should cover the operational, tactical and governance levels of the business unit, always taking into account customers and suppliers of the company. Perez-Franco (2016) highlights these features as fundamental and interconnected components of SCS.

Researches in the literature show works focused on SCS, where it plays a supporting role. In turn, the role is related to SC collaboration (Chen et al., 2017), service level (Tan, 2001); competitive priorities and interrelationships (Chen and Paulraj, 2004), speed delivery (Heikkila, 2002), success degree of SCM (Rosenweig et al., 2003), sustainability performance of SC (Acquaye et al., 2017; Qorri et al., 2018), and performance evaluation of a SCM (Chen and Yan, 2011; Estampe et al., 2013; Gunasekaran et al., 2004; Lima-Junior and Carpinetti, 2007). Among performance evaluationg methodologies, it can be highlighted: Arc of Integration-Performance (Frohlich and Westbrook, 2001), Techniques-Tools Matrix (Cigolini et al., (2004) and Segmentation Tree model (Brun and Castelli, 2008). However, in general, these methodologies analyse SCS, but they disregards its dissociation from business strategy. This fact points to a limitation of studies focused on SCS structuring methodologies, specifically for business unit.

As a result, the literature points to study limitations aimed at SCS structuring. Part of the problem involved in capturing and evaluating SCS, within business unit, occurs due to the inaccuracy of the company strategy itself. According to Bakir and Bakir (2006), usually, the SCS are defined randomly or even they are absent in some sectors, which makes decision making more complex.

Consequently, the purpose of structuring the SCS is to detach the corporation from the dependence on external knowledge, i.e. information derived from scenarios that may or may not apply to the corporation circumstances. Thus, Perez-Franco (2016) presented an SCS Capture and Evaluation model that is based on analysis of the strategy components, obtained through interviews. These data are processed, integrated according to the steps set forth in the methodology, and, then, evaluated on a case-by-case basis and reformulated when necessary. This methodology takes into 
account the plurality and uniqueness of each SCS, as well as the business unit strategy. The methodology proposed by this author was oriented specifically to large companies, where functions and departments are well defined. However, this is not a reality for most micro and small-size enterprise (MSE), where a limited number of employees accumulate responsibilities, and there is no clear division of functions.

Therefore, this work proposes a modified and adapted Perez-Franco (2016) methodology to aid MSE to structure its SCSs. From this, a strategic map is made, which aims to support the strategic planning of the business unit. Thus, Due to the inherent complexity, a soft operational research (SOR) methodology, Value Focused Thinking (VFT), was used to aid decision maker to extract the strategic objective from this map. Thus, in addition to adapting to MSEs, the main contribution of this work is the incorporation of a SOR methodology to assist the manager in the complex task of identifying strategic objectives and verifying the interconnection between them. Through this strategic objectives network is possible to reflect the values and preferences that guide the decision-making.

\section{MATERIALS AND METHODS}

The methodology proposed by Perez-Franco (2016) was chosen and adapted to micro and small-size enterprise (MSE) unit through a case study. The methodology presents different and interdependent phases, which are Capture, Evaluation and Reformulation of Supply Chain Strategy (SCS).

\subsection{SCS capture - proposed adaptation}

According to Perez-Franco (2016), the Capture phase proposes steps to reveal and conceptualize the company SCS, in order to make it explicit as a conceptual system. At this stage, a questionnaire is used as an instrumental approach. This questionnaire was adapted from Perez-Franco (2016) for a MSE by simplifying some questions in order to facilitate the interviewee's understanding of the assessment. This adaptation is also necessary for collecting information about corporation's strategies, as well as the manager's awareness regarding the relevance of the SCM. This process can be divided into two parts: a guide for the facilitator (Table 1), and the questions for the interviewee (Table 2).

Revista Produção Online. Florianópolis, SC, v. 19, n. 4, p. 1262-1288, 2019 
Table 1 - Guide for the facilitator

\begin{tabular}{|c|c|}
\hline \multicolumn{2}{|c|}{ Introduction ( 4min) } \\
\hline $\begin{array}{ll}\text { - } & \text { Mak } \\
\text { disp } \\
\text { - } & \text { Expl } \\
\text { inter } \\
\text { com } \\
\text { - Befo } \\
\text { and } \\
\text { inter } \\
\text { - Intro } \\
\text { as n }\end{array}$ & $\begin{array}{l}\text { ng clear to the interviewee everything is going to be confidential, and they can also } \\
\text { ense with the interview at any given moment. } \\
\text { aining the main objective of coming up with Partial Maps, and reading with them the } \\
\text { viewee's guide. Making clear the entire interview is roughly going to take one hour to be } \\
\text { oleted; } \\
\text { re starting the interview, the facilitator should make clear to the interviewee they can raise } \\
\text { questions at any moment, even though there are pre-determined moments during the } \\
\text { view designed for this purpose; } \\
\text { ducing yourself to the interviewee, and asking whether every rule is clear. Taking notes } \\
\text { eeded, and then announcing the interview has formally started. }\end{array}$ \\
\hline \multicolumn{2}{|r|}{ Questions } \\
\hline $\begin{array}{l}\text { Initial } \\
(\sim 3 \text { min })\end{array}$ & $\begin{array}{l}\text { Asking questions regarding the interviewee's position and duties, but refraining from } \\
\text { asking personal questions. The objective of this section is to place the interviewee's rank } \\
\text { within the hierarchical levels previously established by the company. The following } \\
\text { should be avoided: } \\
\text { - "For how long have you been on this post?" } \\
\text { - "Do you think you could be working in a better position?" } \\
\text { - "Which personal features helped you climb your way up to the post you are in right } \\
\text { - now?" } \\
\text { - "The following are preferable: } \\
\text { - "What is the title of the post you occupy right now?" } \\
\text { - "To what degree you believe you have leverage on the company's strategical } \\
\text { decisions?" }\end{array}$ \\
\hline $\begin{array}{l}\text { Open- } \\
\text { ended } \\
\text { questions }\end{array}$ & $\begin{array}{l}\text { - Based on the place the interviewee occupies in the hierarchy, the questions of this } \\
\text { section should be straightforward and aim to find out the main duties and tasks of } \\
\text { every other posts in the company, under the interviewee's perspective; } \\
\text { - Questions with "what" and "which" are preferable in order to find out tasks, activities, } \\
\text { problems and obstacles; } \\
\text { - Questions with "how" are preferable in order to find out the manner by which some } \\
\text { events occur; } \\
\text { - Questions with "why" are preferable in order to find out logical connections between } \\
\text { intentions and actions; } \\
\text { - Should the interviewee be part of the level } 2 \text { or } 3 \text {, ask questions regarding their } \\
\text { - duties and the duties of other employees at the same level as them; } \\
\text { - Should the interviewee be part of level 1, ask questions about the duties of their } \\
\text { - Dubordinates; } \\
\text { - Tryot judge the content of the responses, only take notes; } \\
\text { in the previous answers, before each following question. Should something be } \\
\text { - unclear, ask the interviewee to elaborate about that precise part of the narrative; } \\
\text { - Asking for examples whenever the interviewee states explanations of concepts or } \\
\text { claims. }\end{array}$ \\
\hline $\begin{array}{l}\text { Semi- } \\
\text { open } \\
\text { ( 15min) }\end{array}$ & $\begin{array}{l}\text { Should something be not fully deployed during the previous section, it can be further } \\
\text { developed and detailed under more strict scrutiny and control by the facilitator. } \\
\text { This section also serves to clarify points not grasped in previous sections, such as the } \\
\text { following examples: } \\
\text { - "What is the main obstacle in your business/area nowadays?" } \\
\text { - "What is exactly the business of your company, in your opinion?" } \\
\text { - "Could you explain in a different way what you meant by this statement?..." } \\
\text { - "What would you say is the main product your customer gets from you?" } \\
\text { - "What is the difference between your product and the competition's?" } \\
\text { - "What are the main traits of your typical customer?" } \\
\text { - "What are the main challenges for the future of your company/area?" }\end{array}$ \\
\hline
\end{tabular}

Source: Adapted from Perez-Franco (2016).

Revista Produção Online. Florianópolis, SC, v. 19, n. 4, p. 1262-1288, 2019 
Table 2 - Questions for the interviewee

\begin{tabular}{|c|c|}
\hline \multicolumn{2}{|r|}{ Questions } \\
\hline Initial & $\begin{array}{l}\text { This section will define the thematic range of the Maps. } \\
\text { - Do you think your ethical values are being well represented in the company's, or do } \\
\text { you think they differ to some extent? Do you believe the company has its own } \\
\text { personality, so to speak? } \\
\text { - Where do you see the company in } 5 \text { to } 10 \text { years? } \\
\text { - Which would you say are the short-term objectives of the company? } \\
\text { - Which would you say are the long-term objectives of the company? } \\
\text { - Have you ever experienced periods where you have had fewer accumulated duties } \\
\text { - to accomplish? } \\
\text { - Does someone else have strategical decision power other than you? } \\
\text { - } \text { else? } \\
\text { - What are the areas of the company directly under your command? }\end{array}$ \\
\hline & $\begin{array}{l}\text { Analysing area by area, always asking "HOW", "WHY" and asking for examples: } \\
\text { - Which are the main duties or tasks within this specific area that are the most time } \\
\text { - } \text { In your opinion, what is the immediate objective that is being achieved whenever } \\
\text { - Homeone executes the aforementioned activities? } \\
\text { - How reliable are your subordinates when it comes to convey and execute the orders } \\
\text { - How do you usually react whenever something does not come out as planned due } \\
\text { to errors of the operators? } \\
\text { - Which are the tools and techniques you use to ensure orders are being followed } \\
\text { - Wccordingly? } \\
\text { - What about misconceptions and wrong planning ideas? How does self-evaluation } \\
\text { - Do you think about externalities in other areas of the company whenever you try to } \\
\text { improve your own area? And how do you evaluate the impact of your planning and } \\
\text { - Hoctions in this situation? } \\
\text { - How many people do you have directly subordinated to your orders in this precise } \\
\text { area? } \\
\text { - What are the duties and tasks of your subordinates in this area? } \\
\text { - Do you share information of this area with your suppliers? } \\
\text { - How much did things change in this area, of which you are aware? How were things } \\
\text { done before? Why did they have to change? }\end{array}$ \\
\hline $\begin{array}{l}\text { Semi- } \\
\text { open }\end{array}$ & $\begin{array}{l}\text { Remaining points that are still not clear from previous sections, and also questions like the } \\
\text { following: } \\
\text { - What is the main obstacle for your area/business nowadays? } \\
\text { - What do you consider the business of your company? } \\
\text { - Which would be the main product your client gets from you, according to your } \\
\text { - How different is your product from your competitions? } \\
\text { - What are the main traits of your typical customer? } \\
\text { - What are the main challenges for the future of your company/area? }\end{array}$ \\
\hline
\end{tabular}

Source: Adapted from Perez-Franco (2016) 
Managers' awareness regarding to the relevance of SCM to competitive advantage in the market niche in which it is inserted is not foreseen as a necessary step according to Perez-Franco's methodology. Thus, at this stage, an adaptation of this methodology to the reality of a MSE is carried out. Perez-Franco (2016) assumed that the professionals responsible for corporate management of the company already understand the positive points in adopting a strategic vision focused on the SCM. Moreover, due to the inherent complexity of the theme, this methodology requires a facilitator, or analyst, who will lead the process.

The questionnaire must to be applied to the company's participants that are somehow relevant in the strategic decisions. This questionnaire contains questions that assess the hierarchical level of the interviewee; open-ended questions about the roles and limits exercised by this employee; structured and specific questions about points that were not clear at the open-ended questions stage, and a closing opportunity in which the respondent can make their final remarks. In each of these groups, the questions aimed to clarify details about the thematic scope of the areas overseen by the manager, with the initial questions, as well as the connection between degrees of distance related to daily practice and the company's general strategy.

The large number of topic subdivisions and the assumption of a large number of employees and hierarchical ranks in a company may seem advantageous for PerezFranco's methodology. This apparent advantage exists because there are a large number of big companies worldwide. However, this approach tends to rule out MSE with few hierarchical degrees and few employees, where there is also an accumulation of roles often by the same employees.

In the case of MSEs, a simplification of the questionnaire is not only necessary in regards to the type of questions asked to the interviewee, but also the number of interviewed participants diminishes. This is true because some questions in PerezFranco (2016) consider the existence of a hierarchy of people fulfilling a task in the company, i.e. quality control, which might be absent and represented by only one responsible person instead of a line of workers under a hierarchical structure.

Hence, addressing superiors in questions can be not only redundant, but also hinder the execution of the assessment, for MSEs personnel routinely execute strategic, tactical and operational tasks. Another point of simplification results naturally from the same characteristic of the MSE is the number of interviews, which also 
decreases due to the fact that there is less personnel in the hierarchical line of the focal area of interest.

The results obtained through the application of the questionnaire were used to build Partial Maps, which are responsible for displaying graphically and interconnecting the layers closest to the tactical and operational levels the layers closest to the top of the pyramid that have the SCS as the central part. Consequently, these Partial Maps were integrated into a Final Strategic Map (FSM).

The aforementioned layers are composed of short sentences, which synthetize the interests and objective observations of the functioning of the SCS in the company. The interconnection among the layers follow a set of predetermined rules that merge and link the sentences the same way the Partial Maps are connected to form the FSM.

Alternatively, an SCS that is not yet operational, although it is being considered for future implementation can also be evaluated, as long as it is expressed as an FSM. Thus, Perez-Franco's methodology seeks to provide a simple and intuitive map for the business unit to carry out an evaluation of its strategy based on the internal wisdom of the managers with the targeted SC.

\subsection{SCS evaluation}

The second stage proposes evaluate the objectives and failures of the company strategy in its current form. At this stage, no adaptations have been made, since any corporation can be evaluated according to the following criteria:

1. Coverage: A good SCS should be comprehensive, that is, it should represent the decision-making areas and interests of the company's supply chain.

2. Clarity: Each SCS objectives, policy and choice should be clearly perceived by decision makers (DM).

3. Feasibility: Given the competencies, resources available, and constraints in the company, the SCS needs to be achievable in practice.

4. Internal Consistency: Refers to Compatibility, Coherence, and Synergy between the different objectives, policies and choices of a SCS.

5. External Consistency: A well-developed strategy should be consistent with the external environment, i.e., its market.

6. Support: The SCS should be support the company's overall strategy. 
7. Sufficiency: it refers to the expectation that each of the overall objectives set for the SC of the corporation is wholly fulfilled, and the corporation's overall strategy is sufficiently supported by the whole chain. Therefore, while the feasibility criterion questions whether the objective can be met, the sufficiency questions whether the objective was actually met.

8. Parsimony: in SCS should use only the resources needed to provide the expected level of support for the overall strategy.

9. Riskiness: Due to market dynamics, uncertainties and incomplete information, among others, SCSs present a certain level of risk. A good SCS should not pose more risk than a company is willing to face.

10. Advantageousness: SCS must be structured in order to provide competitive advantages over other companies.

11. Action ability: the SCS should be specific enough to serve as a good guide for taking actions.

Each criterion is scrutinized based on its Pillars, Principles, Imperatives, and Policies/Choices, as shown in Figure 1. The evaluation criteria explore the relationship between the upper layers ("why") of Imperatives, whereas Imperatives can answer the means to achieve Policies and Choices ("how" the identified concepts operate largely through operational practices).

After the stage of Partial Maps formulation, it is necessary to refine them through subsequent meetings, for the joint analysis of the facilitator and the interviewees. If there is agreement on the effectiveness of the representativeness of the SCS Partial Maps in relation to the SCM areas, they are synthesized with the components of the Core in a Final Strategic Map.

This synthesis occurs with the overlapping of redundant elements between the Partial Maps, and the Core is compounded of synthesized sentences from the company's Mission, Vision and Values, which may be formally expressed or captured during the interviews. After this formulation, it is presented to all interviews participants and, finally, validated or reformulated. 
Figure 1 - Graphic design of a company's SCS position

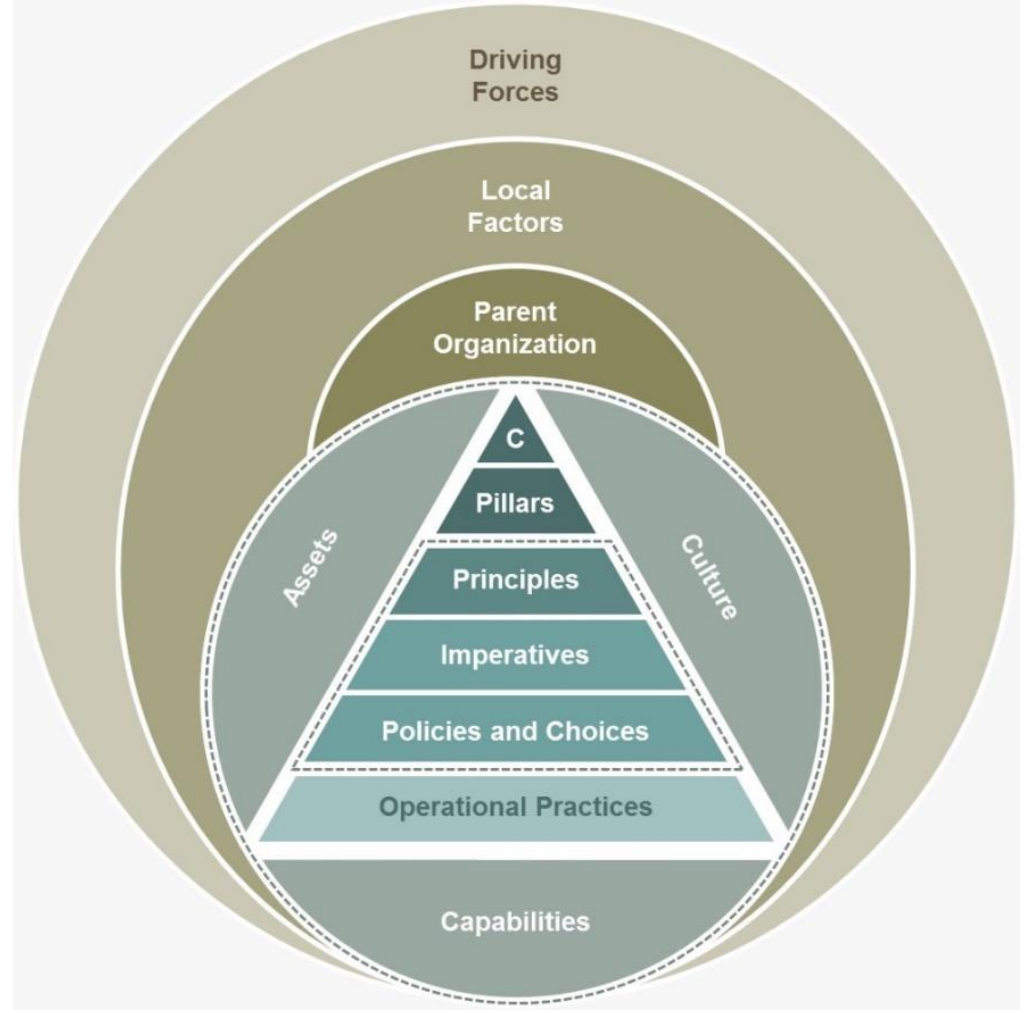

Source: Perez-Franco (2016).

\subsection{SCS Reformulation - proposed adaptation}

According to Perez-Franco (2011), reformulating a SCS means describing a company strategy more relevant than it is currently. In other words, the reformulation is made when some criterion is not being satisfied in the FSM. In the original methodology, the reformulation is carried out through interviews, assuming that the decision makers (DMs) are able to understand the problem well. Since in MSEs concepts are not always clear, it is proposed here the use of a problem-structuring methodology (PSM), which are interactive and participative approaches of soft operational research to help DMs alleviate a complex and problematic situation (Mingers and Rosenhead, 2004).

Therefore, among the existing PSM, Value Focused Thinking (VFT), developed by Keeney (1992), was chosen because it provides a systematic approach to structure complex decisions thinking about values and objectives. "The reason that a DM wishes to make a decision is to achieve something of value. Hence, understanding what it is that one hopes to achieve can lead to both creating better alternatives and to better 
decisions" (Morais et al., 2013). The VFT consists into five steps (Keeney, 1992), but only two steps were considered here, which are:

1. Identification of the Context: The first step is to recognize the decision problem by identifying the specific decision-making situation as well as to gain a better understanding of the objectives of the problem. A list of "wishes" should be drawn from the DM.

2. Structuring of values: from the list of "wishes", a hierarchical relationship between these objectives is created, where these objectives are classified into strategic (it represents the purpose of the DM), fundamental (it is the basis to keep the company in levels of excellence), and means (this represents the degree to which the fundamental objectives can be achieved). For this, the "Why Is That Important?" test is used.

As a result, there is a network of objectives, which illustrates the relationships between objectives from the DM's view of SCS construction.

\section{CASE STUDY}

The company, subject to the case study, operates in the women underwearmanufacturing segment, located in Santa Cruz do Capibaribe of Pernambuco state in Brazil. It is part of the country's second most important local productive arrangement (LPA) of apparel manufacturing. This is classified as a small-size enterprise, thus it has only one business unit.

Based on the number of employees (only 18) and their hierarchical positions, the interviews were conducted exclusively with the higher management of the company, since only she accumulates management responsibilities and makes all strategic decisions.

All products are for resale, i.e., the company does not market directly to the end customer. The company has a strict production criterion, due to the complex degree of variety of products. Firstly, it does not take more than three orders at a time, which must be processed within 45 days. Each order usually ranges from 300 to 800 units, which results in production ranging from 900 to 2400 units per cycle. These figures represent peak production in high season. Secondly, raw material inventory control is 
directly linked to production through continuous analysis. Moreover, even with a very wide range of product variability, they share many equals inputs (fabric, elastic, trim etc.), which facilitates control by the managers.

Although there is a great deal of concern with all the existing functions in the company, it demonstrated a lack of formal background regarding the production balancing, material organization, factory layout and the transportation of both finished products and raw materials.

\section{RESULTS AND DISCUSSIONS}

\subsection{SCS Capture - application of proposed adaptation}

The company aims to address areas related to the improvement of SCM, specifically Customer Relationship Management, Logistics and planning along with the suppliers of the raw material in order to improve the production of consumer goods. Findings about the aforementioned area happened during the first interview with the only responsible for the strategic planning of the MSE. The interviewer, or facilitator, formulated the Partial Maps based on the interview and refined them during a subsequent of two meetings with the responsible manager. By following the adaptation of the methodology by Perez-Franco (2016), it was possible then to restructure the sentences stemming from the interviews and formulate the aforementioned Partial Maps.

Then, the facilitator was able to come up with the FSM. For this, there was a need to formulate the Core and Pillars of the Partial maps, which were based both on statements about the company's Mission, Vision and Values, as well as on parts of the interview, and the following can summarize it:

$\checkmark$ Surviving the economic crisis and imported products competition;

$\checkmark$ Putting ethics first in all work spheres;

$\checkmark$ Awareness of the need for adaptability to the market;

$\checkmark$ Seeking technological excellence;

$\checkmark$ Reduction of operational and logistic costs;

$\checkmark$ Always valuing the brand recognition;

$\checkmark$ Always seeking to stand out compared to competition's raw materials. 
Regarding the thematic scope, it was initially composed of five areas belonging to the company's SC, listed according to their degree of importance for the manager, according to the suggestion from Perez-Franco (2016), as following:

$\checkmark$ Finances: refers to the accounting activities of the company. The most significant weight of this area is due to the fact that improvements in the factory are only possible with a good budget planning; besides there is a great sensitivity for investments in relation to the individual contribution margin of each item.

$\checkmark$ Sales: encompasses contact with new and old customers for discounts and new products updates. It is the second most important area for the manager in relation to SCS because the competitive advantage over the competition is better achieved in this way, thus ensuring a greater share of the market niches ahead the competition.

$\checkmark$ Creative: it is responsible for the development of new items with aesthetic features that stand out more than the competition's, at an affordable price to the client. It plays an important role in SCS by being directly responsible for the difficulty degree in producing the items. Consequently, it is a strategic-guided area in the use of resources.

$\checkmark$ Production: comprises not only manufacturing the items but also the inventory management and machinery maintenance. SCS benefits from this area through the reduction of staff costs with regard to Ergonomics, with inventory regard to the correct use of raw material, and with processes regard to technological evolution of cutting, packaging and sewing of the manufactured underwear.

$\checkmark$ Quality: it is highlighted as important for SCS because it represents the brand's reputation towards the customers. Ensuring that defective products do not reach the market is as important as ensuring that well-manufactured products will not be considered defective, hence delaying the delivery schedule and increasing the reworking costs of the items.

Once the SCS of the company has been captured, the evaluation uses the FSM, as shown in Figure 2, which describes the current SC strategy in the corporation. The description of Figure 2 is shown in appendix A. It is observed that FSM is made of sentences containing direct information, which is composed by terms more casual than 
technical. This feature is intentional, and its observation is not usual, since many of the SCS managers and developers have previous knowledge of technical nature.

\subsection{Evaluation of the criteria}

The FSM serves as input for the evaluation phase. The first criterion to be evaluated was Coverage. Due to the redundancy between the strategies created, the manager managed to reduce the areas of the company from five to three. Consequently, all areas were covered, satisfying this criterion.

In a final interview, the manager was able to visualize connections between elements of the base (operational) and the top of the pyramid (mission, vision and values) independently. This shows that there was Clarity in SCS.

For this study, the Feasibility criterion needed to be cautiously analysed, through an analysis in the factory's daily life. It is because the more basic FSM levels have a causal link with the top of the pyramid. For instance, identifying the bottlenecks in processes for cost reduction is tied to the optimization of the company's entire capital for maximum improvement. However, this does not mean that it is the only way to reach the strategic objectives.

As described earlier, the criterion of Internal Consistency is divided into three sub criteria: compatibility, coherence and synergy. Once the criteria clarity, coverage and feasibility have been met, all strategies are related, and there is a relation between the top (objectives, policies and choices) and base (operational practices) of the pyramid, the compatibility and coherence are validated by the FSM. Moreover, the synergy was also valid, as the manager affirmed that the principles "Turning the anticipation of customer's needs into a source of profit for the company" and "Reducing the inevitable negative impacts of marketing sector with the customers" reinforce one of the strengths of the strategies.

Regarding the criterion of External Consistency, the manager always works to be in harmony with the external environment. The Core was developed in optimal use of resources, flexibility and focus on the relationship with the customer. This is fully compatible with the type of market niche in which the company works, in a country in crisis and with local and international competitors. 
Figure 2 - Final Strategic Map

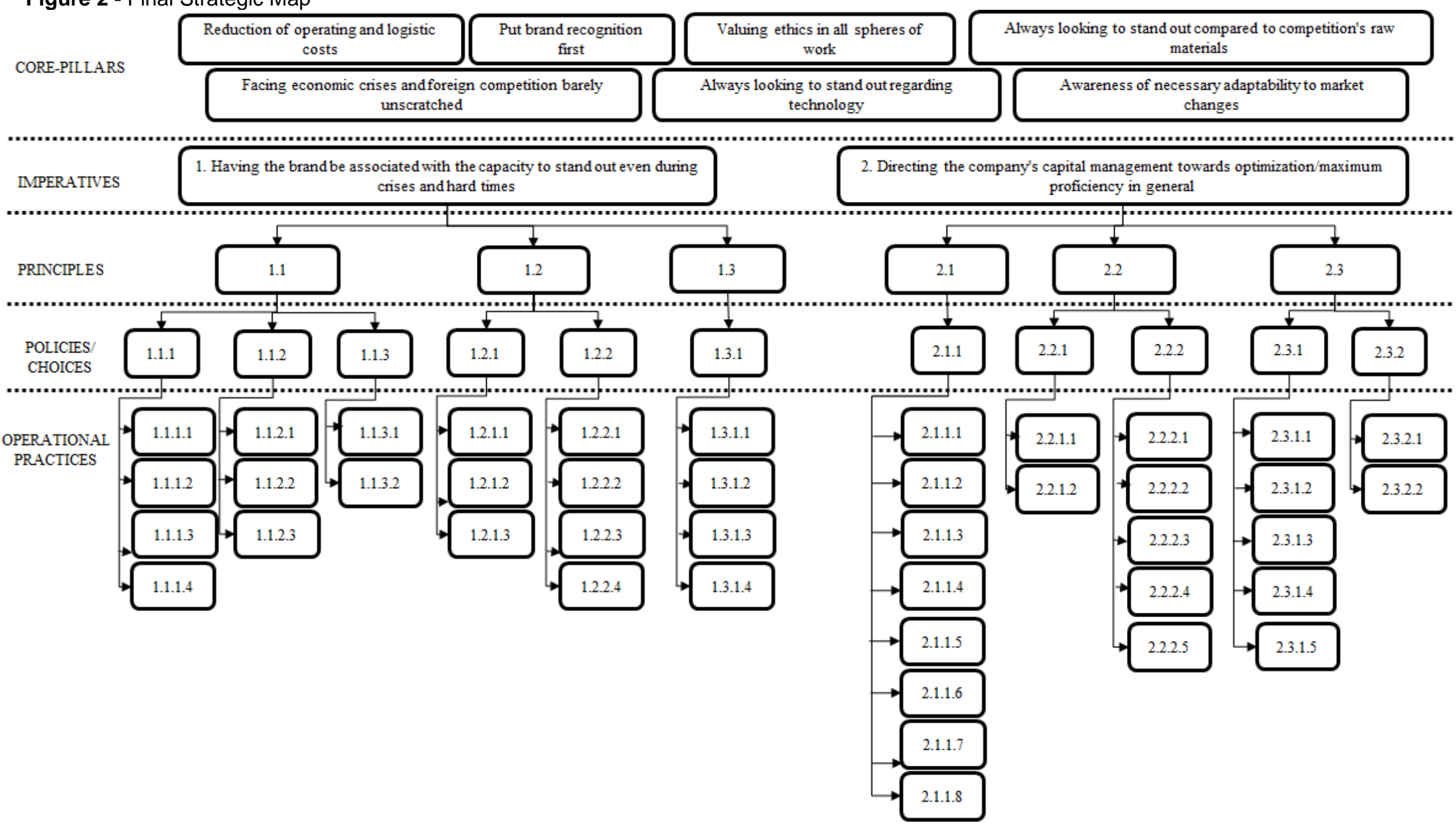


All the SCS described in the FSM under study were focused on the strategy of reducing costs, increasing customer satisfaction and flexibility in the market niche. Thus, it is possible to affirm that SCS and business strategy are compatible with each other and Support one another. Moreover, the factory manager is also an idealizer of the business strategy.

The manager said that the imperative "Having the brand be associated with the capacity to stand out even during crises and hard times" is not fully satisfied with policies and actions. In this way, the Sufficiency criterion is not fully met in the WSF.

Parsimony criterion appears much more as suggestions for the manager than to achieve some purpose. The less effort/steps in the production process exist to achieve the overall objective, the more benefits it will bring to the corporation. In the face of interviews and talks with the manager to understand if the upper and lower layers are in fact the fastest, most economically feasible and most efficient ways to meet global strategies, the manager concludes that the stages defined in the FSM are in fact the most advantageous available.

As the SCS described in the FSM were developed based on "survival" and "flexibility" in the face of a market in crisis and highly competitive, the strategies are consistent with the scenario and, thus, the Riskiness criterion is met.

The manager evaluated as an Advantageousness criterion the flexibility of the company, as it has a large mix of products and various forms of payment. Finally, the Action ability criterion does not apply to the company, since there is no strategy described in the WSF that is not yet in force.

Even before the Reformulation phase, it is possible to notice that the FSM obtained for the MSE is in line with the methodology proposed by Perez-Franco (2016), for there is a performance check for the elements, consisting of asking "why?" from bottom to top and "how?" from top to bottom, starting from any sentence in any layer. Consequently, there must be reasonableness in the responses, according the manager. This was observed in this case.

\subsection{SCS Reformulation - application of proposed adaptation}

From the evaluation of the strategies, it was observed that the sufficiency criterion was not satisfied by the company's policies. In addition, a more accurate 
assessment of the company is necessary to verify the feasibility of the strategies, in order to identify if there are other relationships that will be more advantageous to reach the strategic objectives. Therefore, the reformulation phase was fundamental to create strategies that can satisfy every organization. In this step, the Value Focused Thinking method (VFT) was used in order to structure the objectives.

For that, two meetings with the manager were necessary. The first meeting served to explain the VFT methodology. The second meeting served to apply general questions in order to elicit the manager's values, involving her in a discussion about the decision situation. From the answers, a list of "wishes" was obtained, as follows:

$\checkmark$ Adapt the need to the market;

$\checkmark$ Adapt the work environment to employees;

$\checkmark$ Control production;

$\checkmark$ Customer loyalty;

$\checkmark$ Define roles and persons responsible for the sectors;

$\checkmark$ Develop long-term strategic planning;

$\checkmark$ Do market research to create new products;

$\checkmark$ Ensure the smallest possible number of failures after delivery of the products to customers;

$\checkmark$ Find tools to stimulate product prices;

$\checkmark$ Have differentiated products;

$\checkmark$ Have vendors with autonomy in the negotiations;

$\checkmark$ Implement preventive maintenance;

$\checkmark$ Improve customer service;

$\checkmark$ Increase competitive advantage;

$\checkmark$ Increase quality control;

$\checkmark$ Integrate sectors/departments of the company;

$\checkmark$ Invest in new technology;

$\checkmark$ Keep price low;

$\checkmark$ Maintain a loyal relationship with employees.

$\checkmark$ Maintain contacts with new customers to expand their sales;

$\checkmark$ Manage financial control;

$\checkmark$ Minimize operating costs;

$\checkmark$ Motivate the productive environment; 
$\checkmark$ Negotiate delivery deadlines to avoid delays;

$\checkmark$ Observe delivery dates for orders;

$\checkmark$ Offer customized products;

$\checkmark$ Offer training to employees

$\checkmark$ Participate in consultancies, courses, etc.;

$\checkmark$ Produce within the capacity of the company;

$\checkmark$ Promote promotions;

$\checkmark$ Reduce customer disruption;

$\checkmark$ Reduce environmental impacts;

$\checkmark$ Reduce response time of auxiliary functions to production;

$\checkmark$ Seek continuous improvement;

$\checkmark$ Seek technological excellence;

$\checkmark$ Standardize working methods;

$\checkmark$ Stand out in relation to competition;

$\checkmark$ Survive to economic crisis;

$\checkmark$ Survive to competition of imported products;

$\checkmark$ Withdraw products without sales;

Thus, the manager's values were elicited and converted into objectives. Thus, as strategic objective was defined "Increase competitive advantage", while the fundamental objectives were described as:

$\checkmark$ Minimize operating costs;

$\checkmark$ Seek continual improvement.

$\checkmark$ Seek technological excellence;

$\checkmark$ Stand out in relation to the competition; and

$\checkmark$ Survive to economic crisis.

After that, the objectives network was presented for the manager. She made some complements, comments and adjustments regarding the link between the objectives. She eliminated the following objectives: Adapt the work environment to employees; Ensure the smallest possible number of failures after delivery of the products to customers; Maintain contacts with new customers; and Reduce response time of auxiliary functions to production. After that, she was satisfied, and the final 
objectives network is shown in Figure 3.

\subsection{Management Implications}

This methodology can be taken as a formulation of the Business Strategy and not the company's SCS. This impression might happen due to the number of stages of formalizing internal tacit knowledge rather than interaction at any level with suppliers or customers.

However, the greatest contribution of the application of SCS Capture methodology in a micro and small-size enterprise (MSE) is in the performance assessment of the aforementioned methodology after the adaptation.

In addition, the decision-making profile centralized solely in the company's manager is representative in the LAP of apparel manufacturing in Pernambuco state. Thus, the number of employees interviewed in whatever MSE of the LPA will hardly exceed two. This is reflected in the lack of dynamism of the groups and levels of those in charge.

The reformulation phase was fundamental to create strategies that can satisfy every company. In this stage, a soft operational research approach was proposed in order to structure the objectives. Through VFT, the manager was able to broaden her perception regarding the link between the strategies and about the problem situation, which promoted an expansion of the knowledge of the manager related to the context. 
Figure 3 - Objectives network

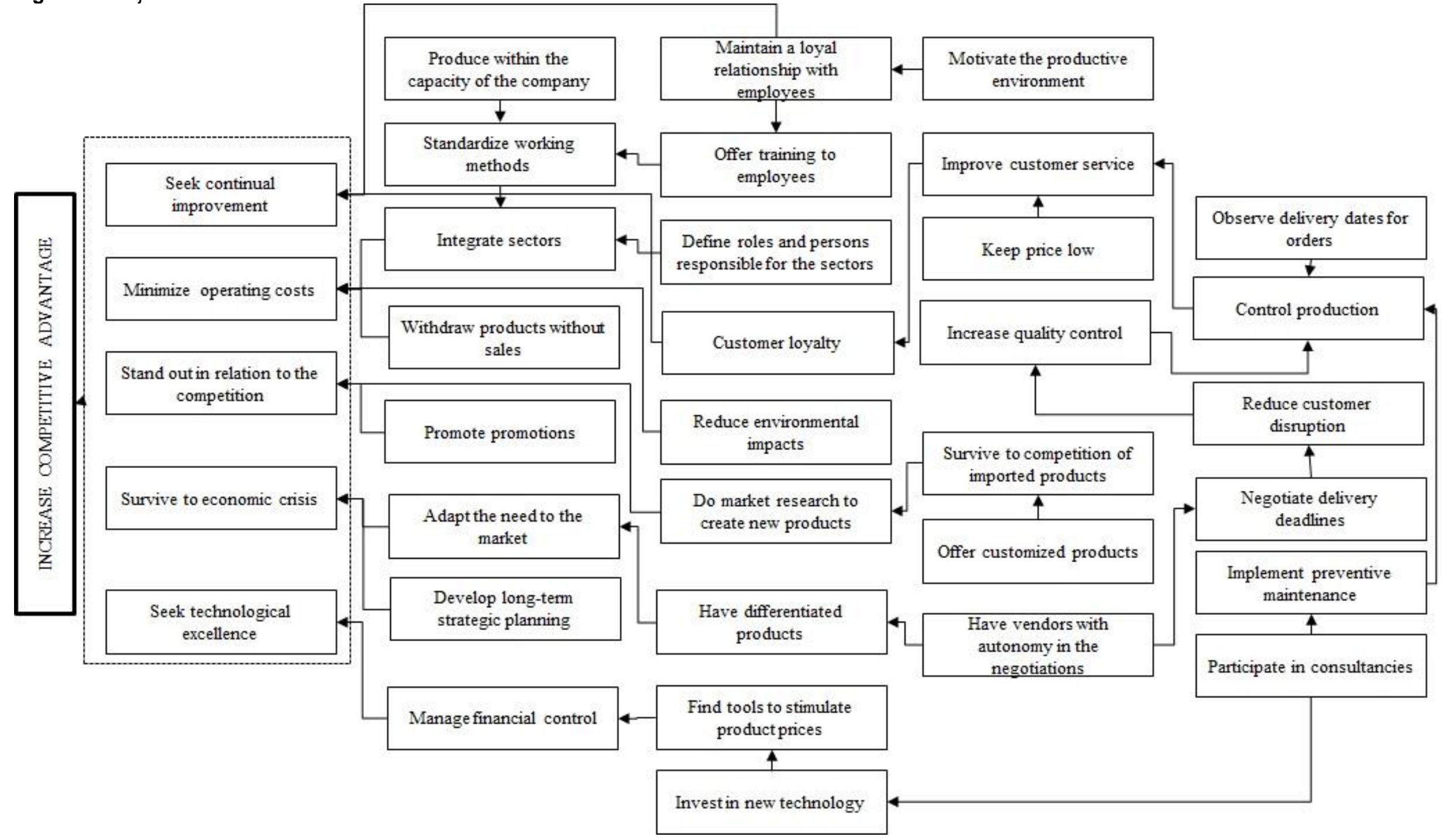

Revista Produção Online. Florianópolis, SC, v. 19, n. 4, p. 1262-1288, 2019 
To sum up, it can be emphasized that the methodology was able to take advantage of all tacit knowledge of the manager to reveal the concealed SCS. The creation of the Final Strategic Map (FSM) proved beneficial both as a device to communicate the SCS as a significant starting point for evaluations and effects of improvements. Moreover, the FSM is a conceptualization of SCS as a bridge between operations and business strategies. Although the FSM has some limitations, the selfawareness that a company obtains in creating a strategic map has proven to be positive both in SCS development as a significant starting point for improvements in the company. Moreover, the structuring proposed here was able to identify the important strategic points and verify the interconnection between them. From this, the manager can develop short- and long-term strategic action plans, keeping the company's pillars firmer to stay competitive.

\section{CONCLUDING REMARKS}

The methodology proposed by Perez-Franco (2016) describes steps and brings recommendations that are beyond the needs of micro and small-size enterprise (MSE). Moreover, this author suggested that everyone in the enterprise has some knowledge about SCS. However, this is not the reality of the MSE, and a stage of awareness has been inserted. Thus, this study applied and adapted the methodology proposed by Perez-Franco (2016) for SCS in a case of small-sized enterprise.

Another highlight related to the adaptation concerns the redundancy of certain stages during the interview phase (similar questions in different groups of questions in the questionnaire), which is considerably extensive and with little contribution to the information acquired by the final stage of semi-open questions. Possibly, the use of more direct and precise questions in the group of open questions would be enough to obtain the relevant information in the assembly of the Partial Maps. Therefore, this would facilitate the preparation of the FSM.

An important contribution to this study is the idea that the SCS of a business unit can be represented as a conceptual system, i.e. a grouping of concepts (theoretical, practical and executable), linking SC business strategy and operations to support more adequately and comprehensively. 
In the second phase of the methodology, no adaptations were necessary, since any organization can evaluate its SCSs according to the general criteria indicated. However, a thorough evaluation of the feasibility criterion is necessary to identify if it is possible to perform some activity in a more satisfactory way for the corporation.

However, the reformulation phase was necessary in order to meet all business strategies. For this stage, a soft operational research approach was used, the VFT, aiming at identifying and structuring the objectives. Through the generated objectives network it was possible to verify the association of one strategy with another, as well as to reflect the values and preferences that guide the decision-making. Therefore, the approach presented allowed to capture, evaluate and reformulate the strategies in a small-sized enterprise, to help and support the manager by developing strategies that were not aligned with CS, and to identify the connection between them.

\section{REFERENCES}

ACQUAYE, A., IBN-MOHAMMED, T., GENOVESE, A., AFRIFA, G. A., YAMOAH, F. A., \& OPPON, E. A quantitative model for environmentally sustainable supply chain performance measurement. European Journal of Operational Research, p. 1-18, 2017. https://doi.org/10.1016/j.ejor.2017.10.057

BAKIR, A., \& BAKIR, V. Unpacking complexity: pinning down the elusiveness of strategy. Qualitative Research in Organizations and Management, v. 1, n. 3, p. 152-72, 2006. https://doi.org/10.1108/17465640610718761

BRUN, A., \& CASTELLI, C. Supply chain strategy in the fashion industry: Developing a portfolio model depending on product, retail channel and brand. International Journal of Production Economics, v. 116, n. 2, p. 169-181, 2008. https://doi.org/10.1016/j.ijpe.2008.09.011

CHEN, I. J., \& PAULRAJ, A. Towards a theory of supply chain management: the constructs and measurements. Journal of Operations Management, v. 22, n. 2, p. 119-150, 2004. https://doi.org/10.1016/i.jom.2003.12.007

CHEN, C., \& YAN, H. Network DEA model for supply chain performance evaluation. European Journal of Operational Research, v. 213, p. 147-155, 2011. https://doi.org/10.1016/i.ejor.2011.03.010

CHEN, L., ZHAO, X., TANG, O., PRICE, L., ZHANG, S., \& ZHU, W. Supply chain collaboration for sustainability: A literature review and future research agenda. International Journal of Production Economics, v. 194, 73-87, 2017. https://doi.org/10.1016/.i.jpe.2017.04.005

CHONG, A. Y-L., OOI, K-B., \& SOHAL, A. The relationship between supply chain factors and adoption of e-Collaboration tools: An empirical examination. International Journal of Production Economics, 122, 150-160, 2009. https://doi.org/10.1016/j.ijpe.2009.05.012 
CIGOLINI, R., COZZI, M., \& PERONA, M. A New Framework for Supply Chain Management: Conceptual Model and Empirical Test. International Journal of Operations and Production Management, 24, 7-41, 2004. https://doi.org/10.1108/01443570410510979

DE CARVALHO GOMES, L., \& KLIEMANN NETO, F. J. (2015). Métodos colaborativos na gestão de cadeias de suprimentos: desafios de implementação. RAE - Revista de

Administração de Empresas, v. 55, n. 5, p. 563-577, 2015. https://doi.org/10.1590/S0034$\underline{759020150508}$

DI SERIO, L. C., \& SAMPAIO, M. Projeto da cadeia de suprimento: uma visão dinâmica da decisão fazer versus comprar. RAE - Revista de Administração de Empresas, v. 41, n. 1, p. 54-66, 2001. https://doi.org/10.1590/S0034-75902001000100007

ESTAMPE, D., LAMOURI, S., PARIS, J-L., \& BRAHIM-DJELLOUL, S. A framework for analysing supply chain performance evaluation models. International Journal of Production Economics, v. 142, p. 247-258, 2013. https://doi.org/10.1016/i.ijpe.2010.11.024

FROHLICH, M. T., \& WESTBROOK, R. Arcs of Integration: An International Study of Supply Chain Strategies. Journal of Operations Management, v.19, p.185-200, 2001. https://doi.org/10.1016/S0272-6963(00)00055-3

GOLICIC, S. L., \& SEBASTIAO, H. J. Supply chain strategy in nascent markets: the role of supply chain development in the commercialization process. Journal of Business Logistics, v. 32, n. 3, p. 254-273, 2011. https://doi.org/10.1111/j.2158-1592.2011.01021.x

GUNASEKARAN, A., PATEL, C., \& MCGAUGHEY, R. E. A framework for supply chain performance measurement. International Journal of Production Economics, v. 87, p. 333-347, 2004. https://doi.org/10.1016/j.ijpe.2003.08.003

HEIKKILA, J. From Supply to demand chain management: efficiency and customer satisfaction. Journal of Operations Management, v. 20, n. 6, p. 747-767, 2002. https://doi.org/10.1016/S0272-6963(02)00038-4

HLIOUI, R., GHARBI, A., \& HAJJI, A. Integrated quality strategy in production and raw material replenishment in a manufacturing-oriented supply chain. The International Journal of Advanced Manufacturing Technology, v. 81, n. 1-4, p. 335-348, 2015. https://doi.org/10.1007/s00170-015-7177-0

HSIAO, H-I., KEMP, R. G. M., VAN DER VORST, J. G. A. J., \& OMTA (ONNO), S. W. F. A classification of logistic outsourcing levels and their impact on service performance: Evidence from the food processing industry. International Journal of Production Economics, v. 124, n. 1, p. 75-86, 2010. https://doi.org/10.1016/j.ijpe.2009.09.010

KEENEY, R.L. Value-focused thinking: a path to creative decision making. Cambridge, MA: Harvard University Press, 1992.

KIM, D., \& CAVUSGIL, E. The impact of supply chain integration on brand equity. Journal of Business Logistics, v. 24, n. 7, p. 496-505, 2009.

https://doi.org/10.1108/08858620910986730

LIMA-JUNIOR, F. R., \& CARPINETTI, L. C. R. Quantitative models for supply chain performance evaluation: a literature review. Computers \& Industrial Engineering, v. 113, p. 333-346, 2017. https://doi.org/10.1016/j.cie.2017.09.022

Revista Produção Online. Florianópolis, SC, v. 19, n. 4, p. 1262-1288, 2019 
MENTZER, J. T., DEWITT, W., KEEBLER, J. S., MIN, S., NIX, N. W., SMITH, C. D., \& ZACHARIA, Z. G. Defining Supply Chain Management. Journal of Business Logistics, v. 22, n. 2, p. 1-25, 2001. https://doi.org/10.1002/j.2158-1592.2001.tb00001.x

MINGERS, J., \& ROSENHEAD, J. Problem structuring methods in action. European Journal of Operational Research, v. 152, n. 3, p. 530-554, 2004.

https://doi.org/10.1016/S0377-2217(03)00056-0

MORAIS, D. C., ALENCAR, L. H., COSTA, A. P. C.S., \& KEENEY, R. L. Using valuefocused thinking in Brazil. Pesquisa Operacional, v. 33, n. 1, p. 73-88, 2013. https://doi.org/10.1590/S0101-74382013000100005

NARASIMHAN, R., KIM, W. S., \& TAM, C. K. An empirical investigation of supply chain strategy typologies and relationships to performance. International Journal of Production Research, v. 46, n. 8, p. 5231-5259, 2008. https://doi.org/10.1080/00207540600847137

OMAR, A., DAVIS-SRAMEK, B., FUGATE, B. S., \& MENTZER, J. T. Exploring the complex social processes of organizational change: supply chain orientation from a manager's perspective. Journal of Business Logistics, v. 33, n. 1, p. 4-19, 2012.

https://doi.org/10.1111/i.0000-0000.2011.01034.x

PEREZ-FRANCO, R., SINGH, M., \& SHEFFI, Y. An approach to evaluate a firm's supply chain strategy as a conceptual system. Center for Transportation and Logistics, Massachusetts Institute of Technology. Retrieved from, 2011. http://web.mit.edu/sheffi/www/documents/Robertopaper23-14-11.pdf

PEREZ-FRANCO, R. Rethinking your supply chain: a brief guide, Center for Transportation and Logistics, Massachusetts Institute of Technology, Cambridge, MA, 2016.

QORRI, A., MUJKIĆ, Z., \& KRASLAWSKI, A. A conceptual framework for measuring sustainability performance of supply chains. Journal of Cleaner Production, 2018. https://doi.org/10.1016/j.jclepro.2018.04.073

RITCHIE, B., \& BRINDLEY, C. Supply chain risk management and performance: a guiding framework for future development. International Journal of Operations and Production Management, v. 27, n. 3, p. 303-322, 2007. https://doi.org/10.1108/01443570710725563

$\mathrm{ROH}$, J., HONG, PAUL., \& MIN, H. Implementation of a responsive supply chain strategy in global complexity: the case of manufacturing firms. International Journal of Production Economics, v. 147, p. 198-210, 2014. https://doi.org/10.1016/j.ijpe.2013.04.013

ROSENWEIG, E. D., ROTH, A. V., \& DEAN, J. W. The influence of an integration strategy on competitive capabilities and business performance: an exploratory study of consumer products manufacturers. Journal of Operations Management, v. 21, p. 437-456, 2003. https://doi.org/10.1016/S0272-6963(03)00037-8

TAN, K. C. A framework of supply chain management literature. European Journal of Purchasing \& Supply Management, v. 7, p. 39-48, 2001. https://doi.org/10.1016/S09697012(00)00020-4

VITORINO FILHO, V. A., DE CAMARGO JÚNIOR, J. B., PIRES, S. R. I., ARGOUD, A. R. T. $\mathrm{T}$. The international academic production in practices and initiatives of supply chain 
collaborative management: a bibliometric study. Revista Produção Online, v. 17, n. 2, p. 567-591, 2017. https://doi.org/10.14488/1676-1901.v17i2.2462

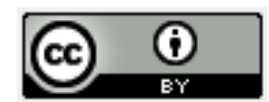

Artigo recebido em: 24/09/2018 e aceito para publicação em: 01/12/2019

DOI: http://dx.doi.org/10.14488/1676-1901.v19i4.3393 


\section{APPENDIX A - THE DESCRIPTION OF FIG.2}

1. Having the brand be associated with the capacity to stand out even during crises and hard times

1.1. Turning the anticipation of customer's needs into a source of profit for the company

1.1.1. Improving customer service

1.1.1.1. Knowing production costs to each manufacture good for discounts and sales offerings

1.1.1.2. Bartering with customer regarding price per unit when closing a deal

1.1.1.3. Letting the customer know about production/processing betterment

1.1.1.4. Taking unsuccessful goods out of the offering catalogue beforehand

1.1.2. Standing out compared to local competition

1.1.2.1. Applying marketing formal know-how in the business

1.1.2.2. Granting barter autonomy to sales personnel

1.1.2.3. Reaching out to potential new customers

1.1.3. Establishing a good relationship and alliances with recurring customers

1.1.3.1. Reaching out to established customers and letting them now in advance about new products

1.1.3.2. Negotiating flexible deadlines in order to avoid unplanned delays

1.2. Reducing the inevitable negative impacts of marketing sector with the customers

1.2.1. Turning the customer into the main source of information for the creation of new products

1.2.1.1. Creating a good atmosphere of nigh expectancies to the customer

1.2.1.2. Finished goods having unique traits to each customer

1.2.1.3. Always accompanying customer's profile and trends

1.2.2. Integrating research \& development with production sectors

1.2.2.1. Coming up with an aesthetically different and unexpansive product

1.2.2.2. Measuring the impact of product's traits in the process of production

1.2.2.3. Centralizing both design and production decisions

1.2.2.4. Developing eventual new add-ons to products

1.3. Reducing chances of troubles for the customers regarding trust in the product

1.3.1. Decreasing as much as possible the number of faulty products after shipment to customer

1.3.1.1. Aiming to one-by-one quality inspection

1.3.1.2. Remanufacturing before recalling mentality

1.3.1.3. Assessing and knowing the most common production flaws

1.3.1.4. Strict personnel training for quality control

2. Directing the company's capital management towards optimization/maximum proficiency in general

2.1. Maintaining responsibility in corporate governance

2.1.1. Managing daily budget

2.1.1.1. Updating ledger software

2.1.1.2. Keeping the total balance up to date in a monthly basis

2.1.1.3. Weekly checkout of customer's payments

2.1.1.4. Monthly budgeting via software

2.1.1.5. Yearly scheduling and budgeting based on sales

2.1.1.6. Calculating production capacity

2.1.1.7. Financial information exchange with customers, whenever necessary

2.1.1.8. Scheduling purchases of raw material throughout the month (cycle)

2.2. Increasing competitive advantage

2.2.1. Investing in both machinery and personnel improvement in order to better handle and use unfinished goods while manufacturing

Revista Produção Online. Florianópolis, SC, v. 19, n. 4, p. 1262-1288, 2019 
2.2.1.1. Directing a fraction of net profit to new machinery

2.2.1.2. Scheduling consultants screenings and appointments along with partners in order to share costs

2.2.2. Keeping prices low

2.2.2.1. Calculating the average contribution margin of each product

2.2.2.2. Passing along production costs of some products to others in a planned manner

2.2.2.3. Researching a better technique to finding out the real cost per minute of work

2.2.2.4. Calculating the production cost of each product element of each finished product

2.3. Stabilizing and controlling production having in mind a more realistic and long term strategic planning

2.3.1. Increasing production management's effectiveness in order to reduce costs from this area to the customer

2.3.1.1. Applying tested ergonomics techniques

2.3.1.2. Standardizing time and motion

2.3.1.3. Balancing production and finding bottlenecks

2.3.1.4. Finding out and applying better techniques for measuring individual productive efficiency

2.3.1.5. Changing the standard from seconds to minutes in order to make calculations easier

2.3.2. Decreasing feedback time of other sectors to production

2.3.2.1. Turning inventory management into an activity overseen by production

2.3.2.2. Turning preventive maintenance into an activity overseen by production 